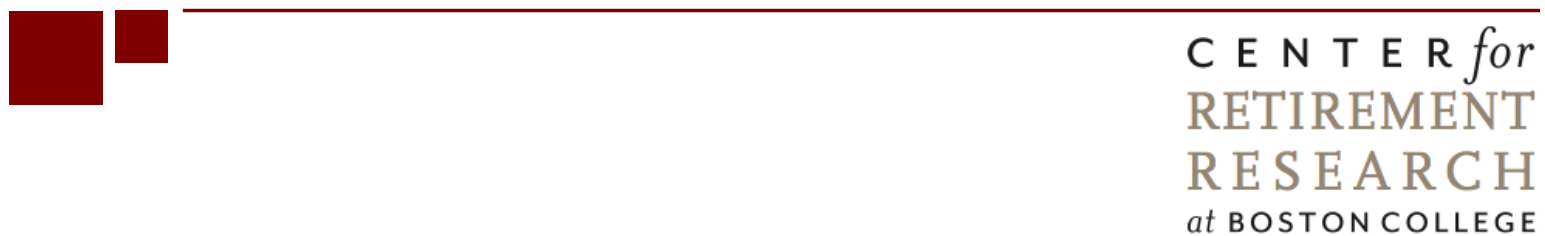

\title{
LOWER-INCOME INDIVIDUALS WITHOUT PENSIONS: WHO MISSES OUT AND WHY?
}

\author{
April Yanyuan Wu and Matthew S. Rutledge
}

CRR WP 2014-2

Submitted: January 2014

Released: March 2014

\author{
Center for Retirement Research at Boston College \\ Hovey House \\ 140 Commonwealth Avenue \\ Chestnut Hill, MA 02467 \\ Tel: 617-552-1762 Fax: 617-552-0191 \\ http://crr.bc.edu
}

The research reported herein was pursuant to a grant from the Ford Foundation. The findings and conclusions expressed are solely those of the authors and do not represent the views of the Ford Foundation or Boston College. The authors are grateful for excellent research assistance from Jacob Penglase, Natalia Orlova, and Dina Bleckman. All errors are the authors'.

(C) 2014, April Yanyuan Wu and Matthew S. Rutledge. All rights reserved. Short sections of text, not to exceed two paragraphs, may be quoted without explicit permission provided that full credit, including (C) notice, is given to the source. 


\begin{abstract}
In 2010, only 19 percent of individuals ages 50-58 whose household incomes were less than 300 percent of the poverty line participated in a pension of any kind at their current jobs, compared to 56 percent of those above 300 percent of poverty. This paper investigates this pension gap. In particular, we decompose the pension participation rate into its four elements in order to compare coverage between higher- and lower-income individuals: 1) the fraction of people who are currently working (the employment rate); 2) the fraction of workers who are in firms that offer pension benefits to at least some workers (the offer rate); 3) the fraction of workers who are eligible for pension benefits, conditional on being in a firm where it is offered (the eligibility rate); and 4) the fraction of workers who enroll in a pension plan when they are eligible (the take-up rate). We find that the substantial pension gap between higher- and lowerincome individuals is driven primarily by the lower-income group’s lower employment rate and the smaller probability of working for an employer that offers pensions; when lower-income workers do have a pension plan at work, their eligibility and take-up rates are nearly equivalent to higher-income workers. We also find that the factors associated with a higher value for each element of pension participation are very consistent: higher education and income, previous pension history, and job characteristics including firm size, occupation, job tenure, and union status. Together, these findings suggest that policies such as automatic enrollment that focus on pension eligibility or take-up are unlikely to close the pension coverage gap between older, lower-income individuals and their higher-income contemporaries; instead, greater pension participation requires more jobs and, in particular, more "good jobs.”
\end{abstract}




\section{Introduction}

In 2010, only 19 percent of individuals age 50-58 whose household incomes were less than 300 percent of the poverty line participated in a pension of any kind at their current jobs, compared to 56 percent of those above 300 percent of poverty. ${ }^{1}$ Individuals who are currently uncovered may have coverage at some point during their working years or may live with a spouse who is covered, but the vast majority will end up with virtually no pension wealth at retirement. Nearly all of their retirement income will come from Social Security, which was never designed to be the sole source of income for retirees and is scheduled to replace less preretirement income in the future. As a result, many lower-income individuals could suffer large declines in their standard of living when they retire. Demographic shifts, labor force participation trends, and impending system reforms will likely result in Social Security replacing a smaller share of pre-retirement earnings in the future, making the retirement security of lowerincome individuals a serious policy concern (Wu et al. 2013).

While lower participation rates among lower-income individuals are unsurprising, the specific reasons for this behavior are less well known. Since coverage is tied directly to employment, one reason for the lack of coverage is that lower-income individuals are more likely to have a weak attachment to the labor force. To what extent are these individuals regularly employed? If employed, do they have a "good job" - that is, are they working for employers who offer pensions? Do they work enough years, and sufficient hours, to qualify for fringe benefits? Or do they just neglect to take up benefits for which they are eligible?

The issue is important because the policy implications differ. Workers offered a defined contribution (DC) plan in which participation is voluntary and often requires a contribution out of one's salary and into a tax-deferred savings account often choose not to take part in the plan, even when eligible. Existing studies suggest that automatic enrollment would increase the probability of pension take-up (e.g., Madrian and Shea 2001), but only to the extent that potentially affected groups are employed at a firm that offers coverage and are eligible for that

\footnotetext{
${ }^{1}$ Authors' calculations from the 2010 Health and Retirement Study. Households with 300 percent of the poverty line are close to the median of the income distribution, which admittedly strains the definition of "lower income." But much of the left tail of the income distribution is not employed, so focusing on more traditional definitions of low income - e.g., 200 percent of the poverty line or less - would bias in favor of finding employment to be the sole barrier to pension coverage. Our definition includes more lower-income workers; 300 percent of the poverty line, or about \$39,000 of income (based on a weighted average between the one- and two-person households in our sample), represents only the 22nd percentile of the income distribution among households that include at least one person age $50-58$ with any work during the year.
} 
coverage. If the problem of low pension coverage among lower-income individuals is mainly caused by their weak labor market attachment, automatic enrollment is less likely to be effective. If lower-income individuals are more likely to be in jobs that do not offer pension benefits, tax incentives to employer to offer coverage or implementation of so-called "Auto-IRAs," which require all employers without a retirement savings plan and with more than 10 employees to redirect a fixed percentage of an employee's salary to a retirement savings vehicle unless the employee opts out, would be effective policy measures. ${ }^{2}$ Therefore, identifying the reason for the lack of participation is the first step in designing effective pension policies that can help bridge the pension gap.

Using longitudinal data on pensions and employment from the Health and Retirement Study (HRS), this study investigates why older, lower-income individuals face such substantial pension coverage gap. Our analysis starts with quantifying the type and extent of pension coverage for these individuals. We consider the full series of hurdles lower-income individuals face in securing pension coverage by decomposing the probability of receiving a pension into its component parts: 1) the fraction of people who are currently working (the employment rate); 2) the fraction of workers who are in the firms that offer pension benefits to at least some workers (the offer rate); 3) the fraction of workers who are eligible for pension benefits, conditional on being in a firm where it is offered (the eligibility rate); and 4) the fraction of workers who enroll in a pension plan when they are eligible for it (the take-up rate). The analysis then estimates the relationship between each probability and demographic and socioeconomic characteristics, characteristics of the employer-employee relationship, as well as risk aversion. The findings of this study help us quantify the effects of potential reforms on lower-income pension coverage, such as expanding the use of auto-enrollment for those who are offered coverage on the job.

We find that the substantial pension gap between higher- and lower-income individuals is driven primarily by lower-income individuals' weaker labor force attachment and by their lower pension offer rates among those who do work. Once they are offered a pension plan and become eligible for that plan, 80-90 percent of older, lower-income individuals participate. We also find that the factors associated with a higher value for each element of pension participation are very consistent: higher education and income, previous pension history, and job characteristics including firm size, occupation, job tenure, and union status.

\footnotetext{
${ }^{2}$ Karamcheva and Sanzenbacher (2013) provide details on the Obama Administration’s Auto-IRA proposal.
} 
The paper proceeds as follows. Section 2 discusses the background and outlines the theoretical framework for this analysis. Section 3 describes the data and sample construction. Section 4 documents trends in pension participation among older, lower-income individuals and in the component parts of pension participation. Section 5 discusses the econometric specifications and summarizes the results. Section 6 concludes that policies aimed at increasing lower-income pension coverage would be most effective if they focus on employment and job quality, rather than on increasing the incentive for eligible individuals to participate.

\section{Background}

Although Social Security, employer-sponsored pensions, and individual savings are often referred to as the three-legged stool of the U.S. retirement income system, the bottom 40 percent of the income distribution ends up almost entirely dependent on Social Security (Reno and Veghte 2010). Low-income individuals' sole reliance on Social Security would not be a problem if the program provided them with sufficient income to maintain their standard of living. But Social Security currently replaces only 40 percent of pre-retirement earnings for a low earner retiring at age 62, the age at which a plurality of low-wage workers retires. Munnell, Fraenkel, and Hurwitz (2012) find that more than a third of households are never, during their entire work lives, covered by a pension, but the lack of pension coverage is concentrated heavily at the lower end of the income distribution: 75 percent of households in the bottom income quintile at ages 63-73 never had a pension. Therefore, low private pension coverage among lower-income individuals has become a concern of policymakers, and understanding the reason behind this coverage gap is critical.

Individuals hoping to be covered by a pension must clear four hurdles; because each hurdle depends on clearing all the previous ones, tripping over one ends the race. To be associated with a private pension, an individual first must work regularly. Lower-income households, perhaps because of a lack of education and skill, have weak labor force attachment they have higher unemployment, and more frequently leave jobs, either voluntarily or involuntarily, without having another job lined up (Holzer and Martinson 2005). In 2013, about 18 percent of individuals in the bottom of the income distribution are unemployed, and among those who work, only about 30 percent works over 30 hours per week. ${ }^{3}$

\footnotetext{
${ }^{3}$ Authors' calculations from the March 2013 Current Population Survey.
} 
Next, a worker can be covered by a pension only if his employer offers them to any of its employees. The reasoning can be somewhat tautological: to be covered by a pension, workers need to find a "good job," which is usually defined as one that offers a generous fringe benefit package including, of course, a pension. ${ }^{4}$ Previous research makes clear that lower-income workers are less likely to be offered other fringe benefits, including health insurance coverage (Farber and Levy 2000), paid time off and paid maternity leave (Phillips 2004), and life and disability insurance (Levy 2004).

Third, workers must be eligible for pension coverage if it is offered by their employers. Many firms make pensions plans available only to workers with sufficient tenure and number of hours worked. Though the concept of "vesting" - accumulating enough tenure to be eligible for a pension - was more common in defined benefit pension plans, some defined contribution plans make eligibility for an employer match conditional on a minimum number of years working for that employer. Furthermore, part-time workers are less likely to be eligible for any pension plan. ${ }^{5}$

Finally, to be covered, eligible workers must take up the employer's pension offer. Many of the factors that limit pension take-up among workers at all income levels - liquidity constraints, high discount rates, insufficient tax incentives, and insufficient knowledge or financial literacy - are particularly relevant for lower-income workers. Lower-income eligible employees may be less likely to participate in the pension plan because they cannot afford to contribute even a small portion of their wages, their discount rate is sufficiently large to make today's consumption much more valuable than tomorrow's, their low (and possibly negative) marginal tax rate means that they do not benefit from tax-deferred earnings, they do not realize they are eligible, or they might be aware of their eligibility and the optimality of pension saving but still lack the motivation to fill out the paperwork.

The existing literature has found a consistent positive relationship between participation and income levels for workers offered a defined contribution plan. For instance, Bassett, Fleming

\footnotetext{
${ }^{4}$ Another strand of the literature analyzes the growth in employment in industries or occupations with higher or lower average wages (e.g., Abraham and Spletzer 2010). Our definition of job quality focuses more on fringe benefits than on wages. Economic theory suggests that workers face a tradeoff of wages for fringe benefits, but the correlation between the generosities of wages and benefits is actually positive (see Simon 2001 for a review).

${ }^{5}$ Employers with a vesting period do not have to credit employees with fewer than 1,000 work hours in a year with a year of service toward, e.g., earning an employer match (Richter 2013). The work hour total does not take into account usual work status (full-time, part-time, or seasonal), but part time workers clearly will have more difficulty achieving this total.
} 
and Rodrigues (1998) find that a \$1,000 increase in family income leads to a 0.3 percent increase in the probability of participation in a defined contribution plan. Similar conclusions are reached by Huberman, Iyenger and Jiang (2007), Munnell et al. (2009), Butrica et al. (2009), and Poterba, Venti, and Wise (2010) using different datasets. But the literature is less clear on which of the four hurdles to pension participation trip up lower-income individuals.

The only study to our knowledge that decomposes pension participation into some of its components is Karamcheva and Sanzenbacher (2013). Their study uses a bivariate probit regression to account for the fact that pension eligibility differs between pension participants and non-participants. They find a statistically significant positive correlation in the error terms between the pension eligibility and pension participation regressions, suggesting that the lowincome workers who are most likely to be covered by pensions are also the ones most likely to seek out jobs where they would be eligible for pensions. They conclude that this "taste for pensions” parameter suggests that policies that aim to extend coverage to current nonparticipants cannot extrapolate from current participation rates among low-income eligible workers. Instead, newly eligible workers will likely opt out at much greater rates - after all, if they valued pensions, they likely would have sought them out under the existing regime.

Our study differs from Karamcheva and Sanzenbacher (2013) in several ways. First, their sample consists only of workers; their analysis misses the employment margin, which our results suggest is an important hurdle to pension coverage. Second, they do not distinguish between pension offering - that is, working for an employer that offers pensions to at least one employee group - and pension eligibility. This distinction affects the policy prescription, because raising offer rates would require employers to begin offering coverage, while raising eligibility rates would require only the extension of already-existing pensions to more workers. Third, their analysis extends to younger workers, while ours is limited by the data to age 50-plus; while pension participation at lower ages is a long-run policy concern, especially because pension contributions at younger ages have time to compound, individuals approaching retirement without pension coverage face an imminent shortfall in retirement income that requires an immediate fix.

More generally, this paper is the first to systematically decompose pension coverage into all four of the specific mechanical components and explore the determinants of each of these components. Further, the study focuses on lower-income individuals near retirement age, who 
have fewer opportunities to change their current financial status; if they do not have pension coverage currently, the vast majority will end up with virtually no pension wealth at retirement.

\section{Data and Sample}

The study uses data from the 1992 through 2010 waves of the Health and Retirement Study (HRS). HRS is a longitudinal data collection effort begun in 1992 with a cohort of about 10,000 individuals between the ages 51 to 61 who were born between 1931 and 1941.

Additional cohorts have been enrolled over time so that the survey includes 30,500 individuals in 2010 and can be weighted to be nationally representative of the population over the age of 50 .

Respondents are interviewed every two years.

In each wave, respondents are asked whether they have received pension coverage at any time in the previous two years, and if so, what type of their pension coverage: defined benefit, defined contribution (typically a 401(k)), or both. In addition to this self-reported pension status, the HRS includes detailed information on respondents' labor market attachment and on their employers' pension offer and on their eligibility status. These attributes of the HRS provide some important advantages over other nationally representative data sets that have been used to study pension coverage. ${ }^{6}$ HRS asks non-participants whether their employer offers any pension or retirement plans; if they do, non-participants are asked directly whether they are eligible, eligible only if they worked full time, or ineligible. ${ }^{7}$ If the respondents work for a pensionoffering firm (regardless of eligibility), HRS then asks whether their firms offer a defined benefit plan, a defined contribution plan, or both. ${ }^{8}$

\footnotetext{
${ }^{6}$ The other potential source of information about pension coverage is the Survey of Income and Program Participation (SIPP), which Karamcheva and Sanzenbacher (2013) use. SIPP offers a sample with a broader age range, albeit at the expense of a smaller sample of older workers. SIPP asks whether non-participants work for an employer that offers anyone coverage, so the offer rate is available. But SIPP does not ask directly whether a nonparticipant is eligible; non-participants are instead asked why they do not participate, and they may volunteer that they are ineligible, a strategy that likely misses more ineligibility than the direct eligibility question in the HRS. Furthermore, all SIPP panels except the most recent panel (2008) ask about pension coverage only once during the individual's time in the sample, making it difficult to assemble a time series of pension coverage and impossible to estimate an individual fixed effect model.

${ }^{7}$ Those who answer "eligible only if I worked full time" are considered ineligible in our sample; by definition, they are not working full time, or else they would have answered eligible.

${ }^{8}$ We assume that anyone who works at a firm that offers both DB and DC plans is eligible for each. This assumption is problematic for anyone who works at a firm that is transitioning from DB to DC plans, because DB plans may be available only to longer-tenured employees already in the system. The assumption would lead, therefore, to overestimating the DB pension eligibility rate, and underestimating the DB take-up rate. But only 3 percent of the sample works at a firm offering both plans, so this error is likely rare.
} 
The HRS provides imputations for many income and wealth questions, and we use these imputations whenever they are available. Imputations are not provided for the earnings and incomes of non-respondent co-residents - e.g., adult children living with the HRS respondents for every wave. Therefore, we use the U.S. Census poverty thresholds for a one-person household for widows and for a two-person household of for married couples; income earned by other household members is disregarded.

Our primary sample consists of survey respondents ages 50 to 58, whose household provided a family and financial respondent interview, who answered the pension questions, and whose income is less than 300 percent of the poverty line. While 300 percent of the poverty line is not always considered "lower income" a fairly high threshold is required, since so few Americans who are on the low end of the income distribution have jobs that offer pensions.

Appendix Table 1 summarizes the sample construction. We also exclude individuals who are self-employed, as their pension offering, eligibility, and take-up rates differ significantly from the rest of the labor force, especially for the lower-income self-employed. ${ }^{9}$ These restrictions result in a sample of 2,771 individuals and 12,949 person-year observations.

Table 1 presents descriptive information for our sample. About 22 percent of our sample has a pension at their current job between ages 50 and 58. While the lower-income individuals without pension coverage are about the same age and about as likely to be married or black as those with a pension, they are somewhat less likely to be white, and more likely to be a race other than black or white and more likely to have households with slightly more people. Not surprisingly, those with pensions are substantially better educated, are more likely to own their homes, and have higher incomes. Coverage is highly correlated with the factors that make a worker more likely to be offered a pension: working in a large firm, having a longer job tenure, and working in a white-collar job. ${ }^{10}$ Moreover, low-income individuals without pensions are much less likely to have had a pension in a previous job, emphasizing Karamcheva and Sanzenbacher's (2013) result that pension-holding lower-income workers are a selected sample.

\footnotetext{
${ }^{9}$ About 9 percent of our lower-income sample report being self-employed, and only 4 percent of the self-employed report having a pension.

${ }^{10}$ Pink collar in Table 1 refers to sales and clerical/administrative support.
} 


\section{Trends in Pension Coverage}

Decomposing Pension Coverage: The decomposition procedure follows the analysis employed in health insurance offers, eligibility, and take-up by Buchmueller et al. (2007). ${ }^{11}$ The probability of having a pension through one's current employer is the product of a series of conditional probabilities:

$$
\begin{aligned}
& P(\text { Pension }) \\
& =P(\text { Employed }) \\
& \times\left\{\begin{array}{c}
P(\text { Offered DC Only } \mid \text { Employed }) \times P(\text { Eligible } \mid D C) \times P(\text { Participation } \mid \text { Eligible }) \\
+P(\text { Offered DB Only } \mid \text { Employed }) \times P(\text { Eligible } \mid D B) \times P(\text { Participation } \mid \text { Eligible }) \\
+P(\text { Offered } D B \text { and } D C \mid \text { Employed }) \times P(\text { Eligible } \mid \text { Both }) \times P(\text { Participation } \mid \text { Eligible })
\end{array}\right\}
\end{aligned}
$$

Equation (1) allows for separate estimation of the offer, eligibility, and participation probabilities for Defined Benefit (DB) and Defined Contribution (DC) plans, for two reasons. First, the final probability, $P$ (Participation), is close to one for DB pensions and is significantly lower for DC pensions. ${ }^{12}$ Second, workers in firms that offer DB pensions - for example, government agencies - may have different preferences for job security, flexibility in hours, and cash wages versus fringe benefits than workers in firms offering only DC plans. ${ }^{13}$

Table 2 details employment, offer, eligibility, and take-up rates for individuals ages 5058 with household incomes below 300 percent of poverty, and compares these statistics to the rates for higher-income individuals of the same age. Only about 22 percent of older, lowerincome individuals have private pension plans through their current job; older individuals with household incomes above 300 percent of poverty are almost three times more likely to participate in their employer pension plans. Among older, lower-income individuals who currently have pension plans, about 8 percent (36 percent of the total covered) have only a DB plan; 11 percent (51 percent of the total) have only a DC plan, and about 3 percent have both DB and DC pension plans. A similar proportion of higher-income individuals have only a DB plan,

\footnotetext{
${ }^{11}$ Dushi and Honig (2005) examine the same research question as Buchmueller et al. (2007) but use a strategy that accounts for selection bias in the take-up probability.

${ }^{12}$ Karamcheva and Sanzenbacher (2010) calculate that only 74 percent of workers in firms offering DB plans participate, though this discrepancy could be due to employees' ineligibility.

${ }^{13}$ The framework in equation (1) allows for employees to be offered both DB and DC plans.
} 
but a higher proportion of them (15 percent overall, or 25 percent of those with pensions through their current job) have one of each type.

Decomposing pension participation into its components shows that the substantial pension gap between higher- and lower-income individuals is driven primarily by lower-income individuals' weak labor force attachment: less than half of these individuals are currently working, and less than 60 percent of older low-income workers are offered a pension by their current job. The corresponding numbers for high income counterparts are 79 percent and 82 percent, respectively. Once offered a pension, older low-income individuals are also less likely to be eligible (89 percent vs. 95 percent) and less likely to participate (86 percent vs. 95 percent), but the gaps in these components are much smaller than the gaps in employment and pension offering.

The conditional probabilities allow us to do a back-of-the-envelope calculation of how two recommended policy reforms would impact pension coverage rates. Automatic enrollment would increase the probability of take-up from 86 percent to 100 percent of those who are eligible. To find the hypothetical pension rate, we multiply the probability of working by the conditional probability of working for an employer that offers pensions; we then multiply that by the probability of being eligible for a pension offer conditional on working for a pension-offering employer, and then by the probability of taking up the pension offer conditional on being eligible. In this hypothetical setting, the last probability is 100 percent, but the product of the other probabilities is 25.9 percent, a 3.9-percentage-point increase over the current pension participation rate among older low-income individuals. This calculation suggests only a modest improvement in pension coverage among those most at risk of insufficient retirement income.

Similarly, the Auto-IRA proposal studied by Karamcheva and Sanzenbacher (2013) increases the probability of working for a pension-offering firm to nearly 100 percent, conditional on employment (assuming no exemptions for small employers). The eligibility rate would also increase to 100 percent, as all employees would be eligible. Assuming the take-up rate remained the same, the pension participation rate would increase to 41.8 percent, which is nearly double the current participation rate. This estimate is an upper bound, however, and should be interpreted with caution for two reasons. First, Auto-IRAs may exempt small employers, making the offer rate something less than 100 percent, though still a large number. Second, and more importantly, Karamcheva and Sanzenbacher (2013) find that take-up would 
not be as high among low-income workers not currently offered pensions, because those who currently participate are those who cared enough about pensions to seek out jobs that offered them; with Auto-IRAs, the take-up rate could be substantially lower, as newly-eligible workers may not value pensions.

Better employment prospects for low-income older workers would also make a large difference in pension coverage. If they had the same employment probability as high-income individuals, while all other conditional probabilities stay at their current value, 35.8 percent of low-income individuals would be covered by pensions. If the probability of working for an employer that offered pensions also matched high-income workers, the pension participation rate would be 49.6 percent, not far below the actual high-income participation rate.

Overall, we find that older, low-income individuals do not have pensions mainly because of their poor labor market outcomes, including ending up in "bad” jobs. The gaps with their higher-income counterparts in eligibility and take-up rates are much smaller.

Time Trends in Pension Participation: Figure 1 decomposes the time trend in pension participation since the early 1990s into its component parts for low-income individuals. Consistently about half of the sample worked in each year, though the employment probability dipped in 1996, 2002, and 2008; the latter two years were during recessions, and the dip in 1996 is likely due to a subtle shift in the age composition of the sample. ${ }^{14}$ The area between the top and second-highest lines represents the proportion of low-income individuals who were not working at employers that offered a pension; this share was largest in 1992 (23 percentage points) but for the most part has remained in a range of 18-21 percentage points throughout the sample period. The share of individuals who work for a pension-offering employer but were not themselves eligible remained within a tight range of 1-3 percent until 2004, but in the last two waves this share has widened slightly, to about 5 percent. The share who are eligible but do not take up pension coverage has also increased to about 5 percent, from an average of about 3

\footnotetext{
${ }^{14}$ For the time trend analysis, we restrict our sample to those ages 54-58 in each wave. The HRS adds new cohorts only every six years, which means that the sample has very few people in their early 50s in 1996, 2002, and 2008, right before new cohorts were added. In these years, the sample is somewhat older, and many respondents will be retiring or transitioning to bridge jobs, so the probabilities all will be lower. Limiting the sample to ages 54-58 makes for a more consistent comparison. We also excluded the 2010 wave due to its small sample size, because the Mid-Boomer cohort (born 1954-1959) had yet to be added to the version of the HRS that includes imputations by researchers at the RAND Institute at the time when we conducted the analysis (the data were added in December 2013).
} 
percent before 2004. These trends indicate that pension participation among low-income individuals has fallen off since 2002 in nearly all of its components: a lower employment rate, more ineligibility, and a lower take-up rate.

Figure 2 repeats the exercise with individuals ages 54-58 with household incomes above 300 percent of the poverty line. The two figures are graphed on the same scale, so the degree to which higher-income individuals have greater pension coverage is clear. The trend in employment is slightly positive, with dips in the same years as the low-income sample. As with the low-income sample, there have been slight increases in the share who work for a pensionoffering employer but are not themselves eligible and those who are eligible but do not take-up the pension. Overall, however, pension coverage has actually increased both because of the slight growth in employment, and because the share of the high-income sample that is employed at non-offering employers fell slightly.

In summary, we find that the pension participation gap between high- and low-income older individuals, which was already substantial, has widened considerably in recent years. The divergent patterns in the employment and take-up rates seem to be the drivers of this widening gap.

\section{Determinants of Probability of Having a Pension among Older, Low Income Individuals}

Empirical Strategy : In this section, we explore the determinants of each component of the probability of having a pension among older, low-income individuals. Our specifications are variants of the following model:

$$
Y_{i t}=\beta E_{i t}+\alpha J_{i t}+\delta_{t}+G_{i t}+\varepsilon_{i t}
$$

where $Y$ is the probability of individual $i$ in year $t$ having a pension, the probability of working currently, the probability of working for an employer that offers a pension plan (separately for DB only, DC only, and both DB and DC plans), the probability of being eligible for the pension plan conditional on the employer offering a plan (for DB only, DC only, and both), and the probability of taking up the pension plan conditional on being eligible. $\delta$ is a set of indicator variables for waves 1992-2010 to control for nationwide economic changes in any given time 
and $G$ is a set of indicator variables for region of residence. The vector of job characteristics, $J$, includes firm size, occupation, job tenure, and union status. ${ }^{15}$

The standard life cycle model suggests that demographic and economic factors are important determinants of the current saving rate, and thus pension plan participation. Therefore, the set of socioeconomic variables, $E$, includes age, gender, education, marital status, family size, and per-person income. We also include home ownership status as a proxy for wealth. The regression with employment as the outcome variable controls for the indicators of fair or poor health status and the presence of work-limiting health conditions in order to capture the ability to work. The employment regression model also includes spousal income, to capture the interaction between spouses' labor supply, which has been widely discussed in the literature (Heckman 1974, for example). Finally, $E$ includes four categories of risk aversion, from the least to the most. The sample consists of individuals ages 50 to 58 with household incomes under 300 percent of the poverty line.

Summary Statistics by Pension Participation Component: Tables 3 through 6 present unadjusted mean differences for each component of the probability of having a pension among older, lower-income individuals, arranged by their status. Table 3 compares the characteristics of workers to those of non-workers. Overall, those who are currently working are less likely to be high school drop-outs and more likely to have graduated from college, more likely to be a homeowner, more likely to be male, and modestly (but statistically significantly) more likely to be white. They are also more likely to have a pension from a previous job.

Table 4 shows differences in observable characteristics by the workers' pension offering status. Those who work for a firm offering pensions are more educated, have significantly higher incomes, and are more likely to be homeowners. Those who are offered a pension are more likely than employees at firms that don't offer pensions to be pink-collar (sales and clerical/administrative occupations) or white-collar and much more likely to work for large firm. They also have longer job tenure and are more likely to be part of a union. This group is also more likely to have had a pension prior to the current job, again suggesting that some workers seek out jobs at pension-offering firms.

\footnotetext{
${ }^{15}$ While the literature points out that the existence of an employer match and whether a plan has an automatic enrollment provision are important determinants of pension participation (Papke and Poterba 1995, Madrian and Shea 2001), the HRS does not include this information for all waves, so we are not able to control for these effects.
} 
Table 5 compares those who are eligible for pension plans offered by the employer to those who are not eligible, conditional on working for an employer offering a pension. The differences between these two groups are less likely to be significant than the differences between employees at firms that do and do not offer pensions, which is consistent with the finding that the difference in employment and job quality is the key driver of the pension gap. Still, workers who are eligible for pensions are less likely to be female (though women make up greater than 50 percent of the sample), are more likely to be married, homeowners, and union members, have a bigger household size, greater income and job tenure, and are more likely to have had a pension at a previous job.

Finally, Table 6 summarizes the differences between those who participate in a pension plan and those who choose not to participate, conditional on being eligible. Again, the differences between those who do and do not take up pension offers for which they're eligible are less likely to be statistically significant than the differences between workers in firms that do and do not offer pensions. Those who take up pension offers are less likely to be high school dropouts, more likely to be homeowners, white-collar workers, and union members, and are more likely to have a pension at a previous job and to have greater income and job tenure. But take-up rates are similar by demographics, most educational categories, marital status, and firm size. Also, workers who take up pension offers are about equally likely to be offered DC plans as those who do not take up pension offers, but pension participants are more likely to be offered DB plans, indicative of the near-automatic take-up for traditional pensions.

Overall, the descriptive statistics show that the differences in pension coverage are greatest between those who are or are not employed and between those who or are or are not working at pension-offering firms. At each step, longer-tenured and higher-income (within the sample of those with household incomes less than 300 percent of the poverty line) individuals are more likely to move in the direction of pension participation. Holders of pensions from previous jobs are especially likely to participate at each step. Despite the Karamcheva and Sanzenbacher (2013) finding of a strong unobserved preference either for or against pensions, this is not an obvious result - conceivably, late-career workers may not seek out additional coverage if they are adequately covered from a previous job, but pension coverage appears to be attractive even at that point in the life cycle. 
Regression Results: Table 7 summarizes the results of the linear probability model regression for each component of pension participation. The first column displays the results for unconditional pension coverage. Columns 2 through 5 describe correlations between key variables and the probability of working, working for a firm that offers pensions conditional on working, being eligible conditional on working at a pension-offering firm, and taking up the pension offer conditional on eligibility, respectively.

The regression results largely replicate the patterns evident in the unadjusted summary statistics, with coefficients of the expected direction and magnitude. We find that older, lowincome individuals who are well-educated, living in a larger family, having relatively higher income, and owning a home are more likely to participate in a pension plan. We also find that those who have a pension from a previous job are more likely to have a pension in their current job. Interestingly, we do not find race and age to be important determinants of the probability of having a pension; this may due to the fact that our analysis is focusing on older individuals. Job characteristics are very important for having a pension, as individuals in small firms and in bluecollar occupations, those with shorter job tenure, and without union membership are much less likely to have a pension. Further, individuals who are least risk averse are also less likely to have a pension; this is consistent with our expectation, since risk preferences are correlated with time preferences, so those who are less risk averse are also less likely to do prudent financial planning and put money aside for retirement.

As expected, individuals who are younger, single, living in a larger household, own a home, and are in good health are more likely to be employed (Column 2). More surprisingly, education has little correlation with working, except that high school graduates are more likely to be working than high school drop-outs (the omitted category), and blacks are more likely than whites to be working. Individuals who have previous labor attachment (as captured by previous pension coverage) have a higher probability of working. We also find intra-family labor market substitution, as spousal income is negatively correlated with the other spouse's labor force participation.

In addition to education and previous pension coverage, job characteristics are strong predictors of the probability of working for a pension-offering employer (Column 3). Older lowincome workers are more likely to be employed by firms with pensions in well-paying pinkcollar occupations at large, unionized firms. And they are likely to stick around: not surprisingly, 
job tenures are longest at pension-offering firms. The last two columns examine the correlations between key variables and the probability of being eligible condition on working for a firm that offers pensions and the probability of taking-up the offer conditional on being eligible, respectively. As in the unadjusted summary statistics, fewer coefficients are statistically significant: age, marital status, household size, all education categories, and homeownership are all statistically insignificant in both the eligibility and take-up regressions. With the hurdles of pension offering taken care of, firm size no longer predicts either eligibility status or the take-up decision, and occupations are uncorrelated with eligibility. However, union status, job tenure, income, and previous pension coverage are still highly correlated with pension eligible status and take-up decision.

The longitudinal nature of the data also enables us to look at what determines the variation over time in pension participation for given older, lower-income individuals. Table 8 summarizes the results from the individual fixed-effects model, which takes into account timeinvariant individual unobservable heterogeneity. The estimates from the individual fixed-effects model are similar to those from the pooled ordinary least squares (OLS). For example, job characteristics are very important to having a pension: in the periods where individuals are in blue-collar occupations, with shorter job tenure, and without union membership, they are much less likely to have a pension. As expected, some of the coefficients that are significant in the cross-sectional model are not significant in the fixed-effects model, such as household size and risk aversion, which may due to insufficient variation in the variables for a given lower-income older individual. ${ }^{16}$

The pension participation decomposition allows for separate offer rates for DB and DC pension plans, but the counterfactual exercise in Section 4 is calculated based on an offer rate for both types of pension plans combined. The results in Table 9 justify this choice: with only a few exceptions, the characteristics of individuals and their jobs do not differ between those offered DB plans and those offered DC plans. In particular, working at a small or medium-sized firm and having low risk aversion are associated with low offer rates for both types of plans. Most other coefficients of similar signs and magnitudes as the results in Table 7 but with larger

\footnotetext{
${ }^{16}$ The fixed effects (FE) model does not include an indicator for having a previous pension, because the interpretation of having a previous pension is somewhat troublesome. In an FE model, the coefficient on having a previous pension variable compares those who gained pension at some period to the combination of those who always have a pension and who never have a pension during the sample window.
} 
standard errors, with similar results for both the cross-sectional and fixed-effects models. Several differences emerge, however: pink-collar jobs are statistically significantly more likely to be offered DC plans than DBs, while being a union member, a blue-collar worker, and a longer-tenured employee are all associated with greater DB offer rates but not greater DC offer rates.

\section{Conclusions}

Pension participation among older, lower-income individuals is shockingly low and shows no sign of improving on its own. Given the modest replacement rates from Social Security, more retirement saving is clearly needed if these individuals are to maintain their standard of living after they retire. Policymakers have tried to close the pension gap among lower-income workers by putting forth a series of proposals to expand coverage. Besides AutoIRAs, other proposals to reform pension coverage include: 1) introducing streamlined products that can be adopted by small businesses, such as the SIMPLE plan which does not require the employer to file an annual financial report and should simplify the procedure of setting up an employer-sponsored pension; 2) the Harkin Plan, which would create a government-mandated, privately managed defined contribution pension program to automatically enroll and withhold earnings for all workers whose employers do not provide plans, and 3) proposals by the National Conference on Public Employee Retirement Systems, as well as proposals by state legislatures on using public plan infrastructure to improve private sector coverage.

Identifying the reason for the lack of participation is the first step in designing effective pension policies that can help bridge the pension gap. This paper seeks to explain why older, lower-income individuals face such a substantial shortfall in their pension participation by decomposing the probability of receiving a pension into its component parts and by then examining the determinants of each component. Our evidence indicates the gap is driven primarily by their weak labor force attachment and by lower pension offering rates when they do work. For each component of pension participation, the strongest positive determinants include higher education and income, holding a pension in a previous job, working for a larger employer for a long tenure in a white-collar profession, and belonging to a union.

Though these results are informative about the reasons for weak coverage rates among the lower-income and their implications for pension reform, the reader should exercise caution in 
interpreting any results as causal. The analysis of determinants of each component of pension participation does not account for potential endogenous selection by workers into employment in pension-offering firms or into pension-eligible positions within those firms by individuals who are most likely to value coverage. Karamcheva and Sanzenbacher (2013) find that without controlling for selection, the estimate of potential coverage increases resulting from reforms is much higher. In future work, we plan to explore whether selection is important in alternative specifications, using Heckman (1979) methods applied to nonlinear models. Furthermore, even though some older, lower-income individuals have a pension now, their accumulation in pension accounts may be negligible; we also plan to examine the level of pension wealth and its accumulation decisions.

The fact that weak labor force attachment and "bad jobs" that limit pension access are more important factors affecting the pension gap between higher- and lower-income older individuals than is opting not to participate when a pension is offered suggests that autoenrollment by itself is unlikely to be effective in closing the pension gap. Improving the job prospects of lower-income individuals - not only so they have more success in finding any job, but so they succeed in finding the types of jobs that offer pensions and other benefits - is likely to increase pension participation among older, lower-income individuals. A greater supply of these "good jobs" requires broad-based economic growth, a much more difficult task than a relatively simple pension reform. Overall, our findings suggest that a single policy response is unlikely to be effective in closing the pension coverage gap among older, lower-income individuals. 


\section{References}

Abraham, Katherine G. and James Spletzer. 2010. “Are the New Jobs Good Jobs?” in Labor in the New Economy, Katharine G. Abraham, James R. Spletzer, and Michael Harper, eds. Chicago: University of Chicago Press.

Bassett, William. F., Michael J. Fleming, M. J., and Anthony. P. Rodrigues. 1998.” How Workers Use 401(k) Plans: The Participation, Contribution, and Withdrawal Decisions.” National Tax Journal, 51: 263-89.

Buchmueller, Thomas C., Anthony T. Lo Sasso, Ithai Lurie, and Sarah Dolfin. 2007. "Immigrants and Employer-Sponsored Health Insurance.” Health Services Research 42 (1, Part 1): 286-310.

Butrica, Barbara A., Howard M. Iams, Karen E. Smith, and Eric J. Toder. 2009. “The Disappearing Defined Benefit Pension and Its Potential Impact on the Retirement Incomes of Baby Boomers.” Social Security Bulletin 69(3): 1-27.

Dushi, Irena and Marjorie Honig. 2005. “Offers or Take-Up: Explaining Minorities’ Lower Health Insurance Coverage.” Working Paper 40. Ann Arbor, MI: Economic Research Initiative on the Uninsured.

Farber, Henry S. and Helen Levy. 2000. "Recent Trends in Employer-Sponsored Health Insurance Coverage: Are Bad Jobs Getting Worse?” Journal of Health Economics 19: 93119.

Heckman, James. 1974. “Shadow Prices, Market Wages, and Labor Supply,” Econometrica 42(4):679-694.

Heckman, James J. 1979. “Sample Selection Bias as a Specification Error.” Econometrica 47(1): 153-161.

Holzer Harry J. and Karin Martinson. 2005. "Can We Improve Job Retention and Advancement among Low-Income Working Parents?” Low-Income Working Families Paper 3. Washington, DC: Urban Institute.

Huberman, Gur, Shena S. Iyengar, and Wei Jiang. 2007. "Defined Contribution Pension Plans: Determinants of Participation and Contribution Rates.” Journal of Financial Services Research, 31:1-32.

Karamcheva, Nadia and Geoffrey Sanzenbacher. 2010. “Is Pension Inequality Growing?” Issue in Brief 10-1. Chestnut Hill, MA: Center for Retirement Research at Boston College.

Karamcheva, Nadia and Geoffrey Sanzenbacher. 2013. "Bridging the Gap in Pension Participation: How Much Can Universal Tax-Deferred Pension Coverage Hope to Achieve?” Working paper. 
Levy, Helen. 2004. "Employer-Sponsored Disability Insurance: Where Are the Gaps in Coverage?” Working Paper 10382. Cambridge, MA: National Bureau of Economic Research.

Madrian, Brigitte, and Dennis Shea. 2001. "The Power of Suggestion: Inertia in 401(k) Participation and Savings Behavior.” Quarterly Journal of Economics 116: 1149-1187.

Munnell, Alicia. H., Richard Kopcke, Francesca N. Golub-Sass and Dan Muldoon. 2009. “An update on 401(k) plans: Insights from the 2007 Survey of Consumer Finance.” Center for Retirement Research at Boston College Working Paper 2009-26.

Munnell, Alicia H., Rebecca Cannon Fraenkel, and Josh Hurwitz. 2012. “The Pension Coverage Problem in the Private Sector.” Issue in Brief 12-16. Chestnut Hill, MA: Center for Retirement Research at Boston College.

Papke, Leslie E. and James M. Poterba. 1995. "Survey Evidence on Employer Match Rates and Employee Saving Behavior in 401(k) Plans.” Economic Letters 49(3): 313-317.

Poterba, James M., Steven F. Venti, and David A. Wise. 2010. "The Rise of 401(k) Plans, Lifetime Earnings, and Wealth at Retirement," in Research Findings in the Economics of Aging, edited by David A. Wise. Chicago, IL: University of Chicago Press.

Reno, Virginia P. and Benjamin Veghte. 2010. "Economic Status of the Elderly in the United States.” Working Paper. Washington, DC: National Association of Social Insurance.

Richter, Robert. 2013. “Revisiting Part-Time Employee Eligibility.” Plan Sponsor, available at http://plansponsor.com/Revisiting_PartTime_Employee_Eligibility.aspx, last accessed December 19, 2013.

Phillips, Katherin Ross. 2004. "Getting Time Off: Access to Leave Among Working Parents.” Working Paper B-57. Washington, DC: Urban Institute.

Simon, Kosali Ilayperuma. 2001. "Displaced Workers and Employer-Provided Health Insurance: Evidence of a Wage/Fringe Benefit Tradeoff?” International Journal of Health Care Finance and Economics 1: 249-271.

Wu, April Yanyuan, Nadia S. Karamcheva, Alicia H. Munnell and Patrick Purcell. 2013. "How Does the Changing Labor Supply Behavior and Marriage Patterns of Women Affect Social Security Replacement Rates?” Social Security Bulletin, 73. 
Figure 1. 54-58 Under 300\% PL Excluding Self Employed

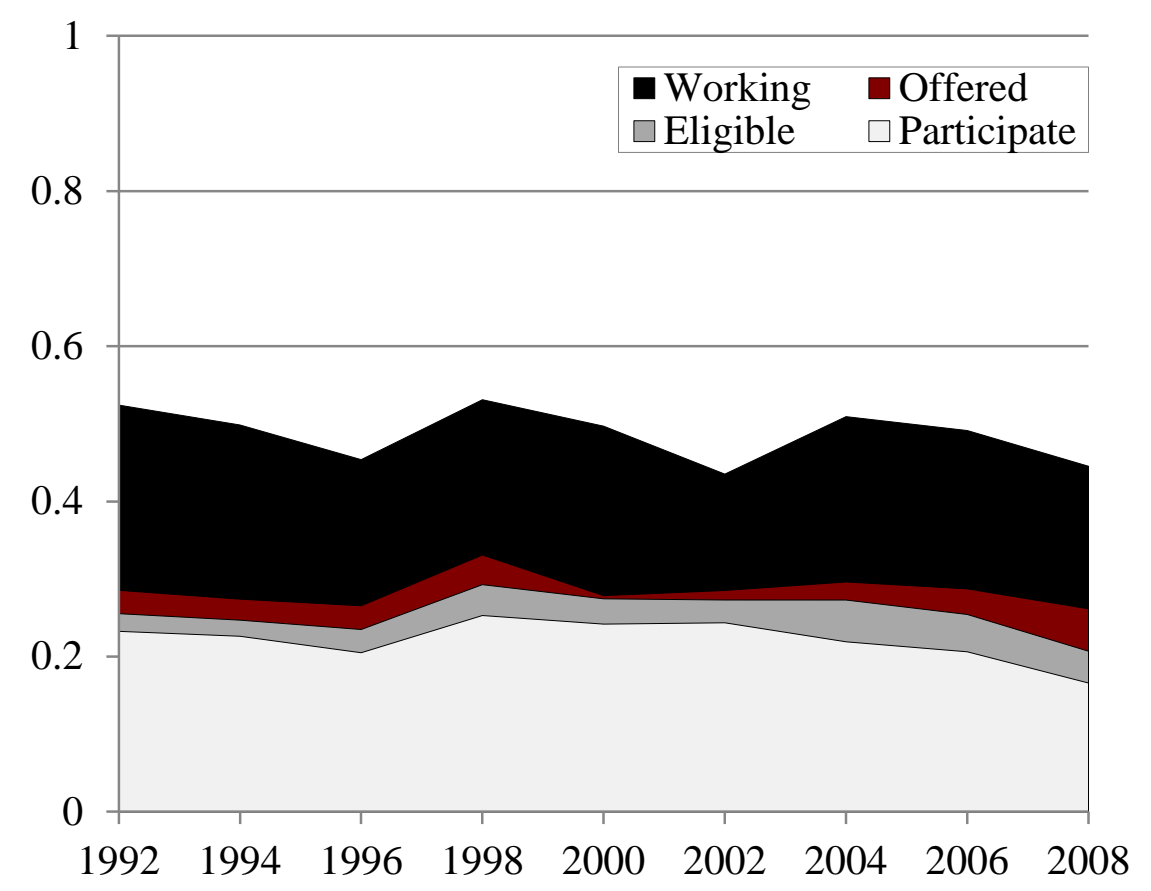

Source:
Figure 2. 54-58 Over 300\% PL Excluding Self Employed

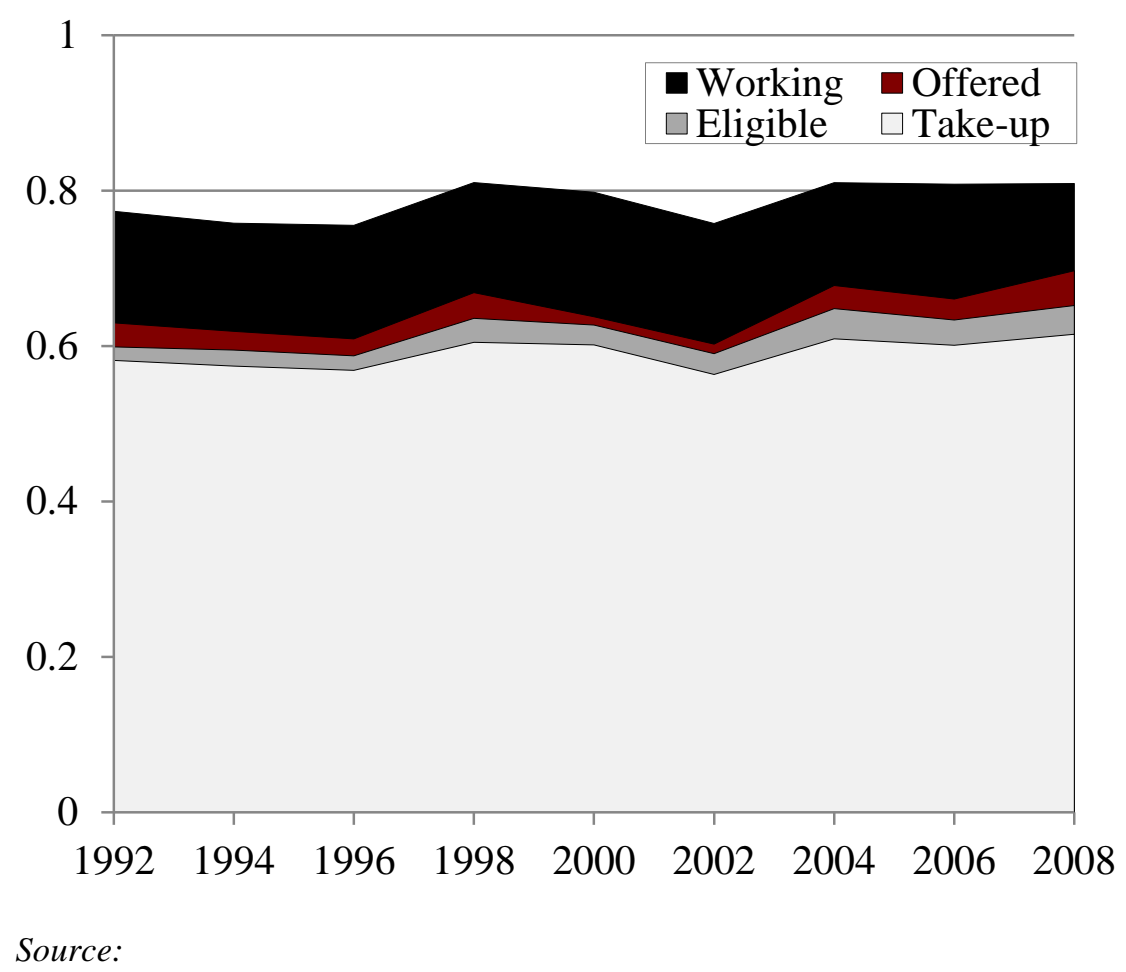


Table 1. Summary Statistics for Those Ages 50-58 and Under 300 Percent of the Poverty Line, by Pension Participation

\begin{tabular}{|c|c|c|c|c|c|}
\hline & \multicolumn{2}{|c|}{ Have a pension } & & \multicolumn{2}{|c|}{ No pension } \\
\hline & Mean & SD & & Mean & SD \\
\hline Age & 55.0 & $(2.2)$ & & 55.2 & $(2.2)$ \\
\hline Female & 57.7 & (49.4) & & 59.6 & $(49.1)$ \\
\hline White & 73.2 & (44.3) & $*$ & 70.4 & $(45.6)$ \\
\hline Black & 18.9 & (39.2) & & 19.4 & (39.5) \\
\hline Other race & 7.9 & (26.9) & $* *$ & 10.2 & (30.3) \\
\hline Some high school & 17.4 & (37.9) & $* * *$ & 33.7 & $(47.3)$ \\
\hline High school & 42.1 & (49.4) & $* * *$ & 37.3 & $(48.4)$ \\
\hline Some college & 24.6 & $(43.1)$ & $* *$ & 20.9 & $(40.6)$ \\
\hline College & 15.8 & (36.5) & $* * *$ & 8.1 & $(27.3)$ \\
\hline Married & 53.9 & (49.8) & & 54.1 & $(49.8)$ \\
\hline Household size & 3.1 & $(1.8)$ & $* * *$ & 2.7 & $(1.6)$ \\
\hline Homeowner & 71.4 & $(45.2)$ & $* * *$ & 18.3 & (38.6) \\
\hline Pink collar† & 30.1 & $(45.9)$ & $* * *$ & 23.8 & $(42.6)$ \\
\hline Blue collar† & 50.4 & $(50.0)$ & $* * *$ & 64.6 & $(47.8)$ \\
\hline White collar† & 19.4 & (39.6) & $* * *$ & 11.6 & $(32.0)$ \\
\hline Job tenure $†$ & 13.2 & (10.1) & $* * *$ & 6.0 & $(7.5)$ \\
\hline Large firm $\dagger$ & 76.6 & (42.3) & $* * *$ & 43.5 & $(49.6)$ \\
\hline Medium firm $\dagger$ & 13.7 & $(34.4)$ & $* * *$ & 16.2 & $(36.9)$ \\
\hline Small firm $\dagger$ & 10.0 & (29.9) & $* * *$ & 40.3 & $(49.1)$ \\
\hline Income (per person) & $\$ 14,538$ & (7494) & $* * *$ & $\$ 10,097$ & $(7258)$ \\
\hline Previous pension & 62.7 & (48.3) & $* * *$ & 13.7 & $(34.4)$ \\
\hline DC pension offered & 62.8 & (48.3) & $* * *$ & 10.6 & $(30.8)$ \\
\hline DB pension offered & 51.2 & $(50.0)$ & $* * *$ & 4.3 & $(20.2)$ \\
\hline Employed & 100.0 & $(0.0)$ & $* * *$ & 34.7 & $(47.6)$ \\
\hline Observations & & & & & \\
\hline
\end{tabular}

Note: Middle column tests the statistical significance of the difference between the pension and no-pension samples: *** $\mathrm{p}<0.01,{ }^{* *} \mathrm{p}<0.05,{ }^{*} \mathrm{p}<0.1$. † Percent of the employed sample.

Source: Authors' calculations from the Health and Retirement Study (1992-2010). 
Table 2. Pension Participation Rate and its Components, 1992-2010

\begin{tabular}{lrrrrrr}
\hline & \multicolumn{2}{c}{ Under $300 \%$ FPL } & & \multicolumn{2}{c}{ Over 300\% FPL } \\
\cline { 2 - 3 } \cline { 6 - 6 } & Prob & $\mathrm{N}$ & & Prob & $\mathrm{N}$ \\
\hline Any pension & 22.0 & 12,949 & & 59.4 & 20,534 \\
$\quad$ Defined benefit only & 8.0 & 12,934 & & 35.4 & 20,528 \\
Defined contribution only & 11.2 & 12,934 & & 39.2 & 20,528 \\
Both DB and DC & 2.7 & 12,949 & & 14.9 & 20,534 \\
Working & 49.0 & & 12,949 & & 79.0 & 20,534 \\
Offered | Working & 59.4 & & 6,369 & & 82.3 & 15,966 \\
Eligible | Offered & 89.1 & 3,595 & & 95.3 & 12,977 \\
Take Up | Eligible & 85.5 & 3,244 & & 95.3 & 12,433 \\
\hline
\end{tabular}

Note: Middle column tests the statistical significance of the difference between the pension and no-pension samples: *** $\mathrm{p}<0.01,{ }^{* *} \mathrm{p}<0.05,{ }^{*} \mathrm{p}<0.1$.

Source: Authors' calculations from the Health and Retirement Study (1992-2010).

Table 3. Summary Statistics for Those Ages 50-58 and Under 300 Percent of the Poverty Line, by Work Status

\begin{tabular}{|c|c|c|c|c|c|}
\hline & \multicolumn{2}{|c|}{ Working } & & \multicolumn{2}{|c|}{ Not Working } \\
\hline & Mean & SD & & Mean & SD \\
\hline Age & 55.0 & $(2.2)$ & & 54.7 & (2.1) \\
\hline Female & 57.5 & $(49.4)$ & $* * *$ & 60.7 & $(48.8)$ \\
\hline White & 72.5 & $(44.6)$ & $* *$ & 69.6 & $(46.0)$ \\
\hline Black & 18.1 & $(38.5)$ & $* *$ & 20.4 & $(40.3)$ \\
\hline Other race & 9.4 & $(29.2)$ & $* *$ & 10.0 & $(30.0)$ \\
\hline College & 11.8 & $(32.2)$ & & 7.8 & $(26.8)$ \\
\hline Some college & 23.0 & $(42.1)$ & $* * *$ & 20.5 & $(40.3)$ \\
\hline High school & 40.3 & $(49.0)$ & $*$ & 36.6 & $(48.2)$ \\
\hline Some high school & 24.9 & $(43.2)$ & $* *$ & 35.1 & $(47.7)$ \\
\hline Married & 54.3 & $(49.8)$ & & 53.9 & (49.9) \\
\hline Household size & 3.0 & (1.8) & & 2.6 & (1.6) \\
\hline Homeowner & 64.2 & $(47.9)$ & $* * *$ & 58.1 & (49.3) \\
\hline Income (per person) & $\$ 13,274$ & $(7,649)$ & $* * *$ & $\$ 8,991$ & $(6,787)$ \\
\hline Previous pension & 43.1 & $(49.5)$ & $* * *$ & 24.0 & $(42.7)$ \\
\hline Currently have pension & 44.9 & $(49.7)$ & $* * *$ & 0 & $(0)$ \\
\hline Observations & \multicolumn{2}{|c|}{6,369} & & \multicolumn{2}{|c|}{6,528} \\
\hline
\end{tabular}

Note: Middle column tests the statistical significance of the difference between the working and not-working samples: $* * * \mathrm{p}<0.01, * * \mathrm{p}<0.05, * \mathrm{p}<0.1$.

Source: Authors' calculations from the Health and Retirement Study (1992-2010). 
Table 4. Summary Statistics for Those Ages 50-58 and Under 300 Percent of the Poverty Line, by Pension Offering

\begin{tabular}{|c|c|c|c|c|c|}
\hline & \multicolumn{2}{|c|}{ Offered pension } & & \multicolumn{2}{|c|}{ Not offered pension } \\
\hline & Mean & SD & & Mean & SD \\
\hline Age & 55.0 & $(2.2)$ & & 55.0 & $(2.2)$ \\
\hline Female & 58.7 & $(49.2)$ & & 55.9 & (49.6) \\
\hline White & 73.1 & (44.4) & & 71.8 & (45.0) \\
\hline Black & 19.1 & (39.3) & * & 16.6 & $(37.2)$ \\
\hline Other race & 7.8 & (26.8) & $* * *$ & 11.6 & $(32.0)$ \\
\hline College & 14.9 & (35.6) & $* * *$ & 7.3 & (26.1) \\
\hline Some college & 25.7 & (43.7) & $* * *$ & 19.3 & (39.4) \\
\hline High school & 41.3 & $(49.2)$ & & 38.9 & (48.7) \\
\hline Some high school & 18.1 & (38.5) & $* * *$ & 34.5 & $(47.5)$ \\
\hline Married & 53.2 & (49.9) & & 55.8 & $(49.7)$ \\
\hline Household size & 3.1 & (1.8) & & 3.0 & $(1.7)$ \\
\hline Homeowner & 68.1 & (46.6) & $* * *$ & 58.8 & $(49.2)$ \\
\hline Pink collar & 30.6 & $(46.1)$ & $* * *$ & 21.1 & $(40.8)$ \\
\hline Blue collar & 51.2 & $(50.0)$ & $* * *$ & 68.1 & (46.6) \\
\hline White collar & 18.2 & (38.6) & $* * *$ & 10.8 & (31.1) \\
\hline Job tenure & 11.3 & (10.1) & $* * *$ & 6.3 & (7.9) \\
\hline Large firm & 77.0 & (42.1) & $* * *$ & 48.6 & $(50.0)$ \\
\hline Medium firm & 13.4 & (34.1) & & 13.5 & (34.1) \\
\hline Small firm & 9.9 & (29.9) & $* * *$ & 38.5 & $(48.7)$ \\
\hline Income (per person) & $\$ 14,242$ & $(7,564)$ & $* * *$ & $\$ 11,905$ & $(7,558)$ \\
\hline Previous pension & 56.6 & (49.6) & $* * *$ & 23.9 & $(42.6)$ \\
\hline Union member & 25.5 & $(43.6)$ & $* * *$ & 7.0 & (25.5) \\
\hline DC pension offered & 58.2 & (49.3) & & 0 & (0) \\
\hline DB pension offered & 43.3 & $(49.5)$ & & 0 & (0) \\
\hline Observations & & & & & \\
\hline
\end{tabular}

Note: Middle column tests the statistical significance of the difference between the offer and no-offer samples: $* * *$ $\mathrm{p}<0.01, * * \mathrm{p}<0.05, * \mathrm{p}<0.1$.

Source: Authors' calculations from the Health and Retirement Study (1992-2010). 
Table 5. Summary Statistics for Those Ages 50-58 and Under 300 Percent of the Poverty Line, by Pension Eligibility

\begin{tabular}{lcccrrr}
\hline & \multicolumn{2}{c}{ Pension eligible } & & \multicolumn{2}{c}{ Pension ineligible } \\
\cline { 2 - 3 } \cline { 6 - 7 } & \multicolumn{2}{c}{ Mean } & SD & & Mean & SD \\
Age & 55.0 & $(2.2)$ & & 55.1 & $(2.3)$ \\
Female & 57.7 & $(49.4)$ & $* * *$ & 67.2 & $(49.5)$ \\
White & 72.7 & $(44.5)$ & & 76.0 & $(42.7)$ \\
Black & 19.3 & $(39.5)$ & & 17.6 & $(38.1)$ \\
Other race & 8.0 & $(27.1)$ & & 6.4 & $(24.5)$ \\
College & 15.2 & $(35.9)$ & & 12.3 & $(32.8)$ \\
Some college & 24.4 & $(42.9)$ & $* * *$ & 36.3 & $(48.1)$ \\
High school & 41.8 & $(49.3)$ & & 37.0 & $(48.3)$ \\
Some high school & 18.6 & $(38.9)$ & $*$ & 14.4 & $(35.1)$ \\
Married & 53.9 & $(49.8)$ & $*$ & 47.6 & $(49.9)$ \\
Household size & 3.1 & $(1.8)$ & $* *$ & 2.8 & $(1.7)$ \\
Homeowner & 69.6 & $(46.0)$ & $* * *$ & 55.6 & $(49.7)$ \\
Pink collar & 30.2 & $(45.9)$ & & 34.4 & $(47.5)$ \\
Blue collar & 51.5 & $(50.0)$ & & 48.2 & $(50.0)$ \\
White collar & 18.3 & $(38.7)$ & & 17.3 & $(37.9)$ \\
Job tenure & 12.2 & $(10.1)$ & $* * *$ & 4.0 & $(6.4)$ \\
Large firm & 77.0 & $(99.4)$ & & 77.0 & $(42.1)$ \\
Medium firm & 13.6 & $(40.6)$ & & 11.4 & $(31.7)$ \\
Small firm & 9.7 & $(34.3)$ & & 11.6 & $(32.1)$ \\
Income (per person) & $\$ 14,387$ & $(7,527)$ & $* *$ & $\$ 13,019$ & $(7,767)$ \\
Previous pension & 58.9 & $(49.2)$ & $* * *$ & 37.4 & $(48.4)$ \\
Union member & 27.1 & $(44.4)$ & $* * *$ & 11.9 & $(32.4)$ \\
DC pension offered & 63.1 & $(48.3)$ & $* * *$ & 16.9 & $(37)$ \\
DB pension offered & 46.8 & $(49.9)$ & $* * *$ & 13.8 & $(34)$ \\
\hline Observations & 3,243 & & & & 352 & \\
\hline
\end{tabular}

Note: Middle column tests the statistical significance of the difference between the eligible and ineligible samples: *** $\mathrm{p}<0.01,{ }^{* *} \mathrm{p}<0.05,{ }^{*} \mathrm{p}<0.1$.

Source: Authors' calculations from the Health and Retirement Study (1992-2010). 
Table 6. Summary Statistics for Those Ages 50-58 and Under 300 Percent of the Poverty Line, by Pension Take-Up

\begin{tabular}{|c|c|c|c|c|c|}
\hline & \multicolumn{2}{|c|}{ Taking up pension } & & \multicolumn{2}{|c|}{ Not taking up pension } \\
\hline & Mean & SD & & Mean & SD \\
\hline Age & 55.0 & $(2.2)$ & & 54.9 & $(2.2)$ \\
\hline Female & 57.7 & $(49.4)$ & & 57.7 & (49.4) \\
\hline White & 73.2 & (44.3) & & 69.7 & $(46.0)$ \\
\hline Black & 18.9 & $(39.2)$ & & 21.6 & $(41.2)$ \\
\hline Other race & 7.9 & (26.9) & & 8.7 & (28.1) \\
\hline College & 15.8 & (36.5) & & 11.6 & $(32.0)$ \\
\hline Some college & 24.6 & (43.1) & & 23.2 & $(42.2)$ \\
\hline High school & 42.1 & $(49.4)$ & & 39.8 & (48.9) \\
\hline Some high school & 17.4 & (37.9) & $* * *$ & 25.4 & (43.5) \\
\hline Married & 53.9 & (49.8) & & 54.2 & (49.8) \\
\hline Household size & 3.1 & (1.8) & * & 2.9 & (1.8) \\
\hline Homeowner & 71.4 & $(45.2)$ & $* * *$ & 58.6 & (49.3) \\
\hline Pink collar & 30.1 & (45.9) & & 30.4 & $(46.0)$ \\
\hline Blue collar & 50.4 & $(50.0)$ & $* *$ & 58.3 & (49.3) \\
\hline White collar & 19.4 & (39.6) & $* * *$ & 11.4 & (31.7) \\
\hline Job tenure & 13.2 & $(10.1)$ & $* * *$ & 5.8 & (7.3) \\
\hline Large firm & 76.6 & (42.3) & & 79.6 & $(40.3)$ \\
\hline Medium firm & 13.7 & (34.4) & & 13.0 & (33.7) \\
\hline Small firm & 10.0 & (29.9) & & 8.1 & (27.3) \\
\hline Income (per person) & $\$ 14,538$ & $(7,494)$ & $* *$ & $\$ 13,482$ & $(7,653)$ \\
\hline Previous pension & 62.7 & $(48.3)$ & $* * *$ & 35.9 & $(48.0)$ \\
\hline Union member & 29.2 & $(45.4)$ & $* * *$ & 14.7 & $(35.4)$ \\
\hline DC pension offered & 62.8 & (48.3) & & 64 & (48) \\
\hline$\underline{\text { DB pension offered }}$ & 51.2 & $(50.0)$ & $* * *$ & 20 & (40) \\
\hline Observations & & & & & \\
\hline
\end{tabular}

Note: Middle column tests the statistical significance of the difference between the pension and no-pension samples: *** $\mathrm{p}<0.01,{ }^{* *} \mathrm{p}<0.05,{ }^{*} \mathrm{p}<0.1$.

Source: Authors' calculations from the Health and Retirement Study (1992-2010). 
Table 7. Linear Probability Model Estimates for Pension Participation Components

\begin{tabular}{|c|c|c|c|c|c|}
\hline Dependent variable & Participate & Working & Offer & Eligible & Participate \\
\hline Sample & All & All & Working & Offer & Eligible \\
\hline \multirow[t]{2}{*}{ Age } & 0.0026 & $-0.0057 * *$ & 0.0056 & 0.0037 & 0.0024 \\
\hline & $(0.002)$ & $(0.003)$ & $(0.005)$ & $(0.004)$ & $(0.005)$ \\
\hline \multirow[t]{2}{*}{ Female } & 0.00213 & -0.0176 & -0.0077 & -0.0082 & 0.00422 \\
\hline & $(0.009)$ & $(0.012)$ & $(0.023)$ & $(0.021)$ & $(0.025)$ \\
\hline \multirow[t]{2}{*}{ Other race } & -0.0055 & 0.0163 & -0.0399 & $0.0471 *$ & -0.0188 \\
\hline & $(0.016)$ & $(0.020)$ & $(0.033)$ & $(0.024)$ & $(0.040)$ \\
\hline \multirow[t]{2}{*}{ Black } & -0.0069 & $0.0336 * *$ & 0.0032 & 0.0272 & -0.037 \\
\hline & $(0.011)$ & $(0.013)$ & $(0.023)$ & $(0.022)$ & $(0.028)$ \\
\hline \multirow[t]{2}{*}{ College } & $0.0566 * * *$ & 0.0099 & $0.143 * * *$ & 0.0425 & 0.046 \\
\hline & $(0.020)$ & $(0.023)$ & $(0.038)$ & $(0.033)$ & $(0.039)$ \\
\hline \multirow[t]{2}{*}{ Some college } & $0.0303 * *$ & 0.0253 & $0.136 * * *$ & -0.0474 & 0.0446 \\
\hline & $(0.012)$ & $(0.016)$ & $(0.030)$ & $(0.030)$ & $(0.035)$ \\
\hline \multirow[t]{2}{*}{ HS only } & 0.0073 & $0.0300 * *$ & $0.0532 * *$ & -0.0149 & 0.0169 \\
\hline & $(0.010)$ & $(0.013)$ & $(0.025)$ & $(0.024)$ & $(0.029)$ \\
\hline \multirow[t]{2}{*}{ Married } & $-0.0168 *$ & $-0.0379 * * *$ & -0.031 & 0.000597 & -0.0399 \\
\hline & $(0.010)$ & $(0.013)$ & $(0.022)$ & $(0.024)$ & $(0.029)$ \\
\hline \multirow[t]{2}{*}{ Household size } & $0.0082 * * *$ & $0.0069 * *$ & $0.013 * *$ & 0.0016 & 0.0063 \\
\hline & $(0.003)$ & $(0.003)$ & $(0.006)$ & $(0.006)$ & $(0.007)$ \\
\hline \multirow[t]{2}{*}{ Homeowner } & $0.065 * * *$ & $0.589 * * *$ & 0.0306 & 0.0297 & $0.0438 *$ \\
\hline & $(0.020)$ & $(0.013)$ & $(0.020)$ & $(0.021)$ & $(0.024)$ \\
\hline \multirow[t]{2}{*}{ Least risk averse } & $-0.0298 * *$ & 0.0017 & $-0.0504 *$ & -0.032 & -0.0467 \\
\hline & $(0.013)$ & $(0.016)$ & $(0.028)$ & $(0.029)$ & $(0.036)$ \\
\hline \multirow[t]{2}{*}{ 2nd least risk averse } & $-0.0241 *$ & 0.0141 & -0.0346 & -0.0461 & -0.0215 \\
\hline & $(0.013)$ & $(0.018)$ & $(0.029)$ & $(0.034)$ & $(0.032)$ \\
\hline \multirow[t]{2}{*}{ Medium risk aversion } & 0.0081 & 0.0040 & 0.024 & -0.00359 & -0.0145 \\
\hline & $(0.013)$ & $(0.014)$ & $(0.025)$ & $(0.023)$ & $(0.028)$ \\
\hline \multirow[t]{2}{*}{ Previous pension } & $0.155^{* * *}$ & $0.0612 * * *$ & $0.222 * * *$ & $0.0788 * * *$ & $0.140 * * *$ \\
\hline & $(0.013)$ & $(0.013)$ & $(0.022)$ & $(0.022)$ & $(0.026)$ \\
\hline \multirow[t]{2}{*}{ Fair or poor health } & & $-0.0301 * *$ & & & \\
\hline & & $(0.012)$ & & & \\
\hline \multirow[t]{2}{*}{ Disability benefits $(0 / 1)$} & & $-0.107 * * *$ & & & \\
\hline & & $(0.013)$ & & & \\
\hline \multirow[t]{2}{*}{ Health limitation $(0 / 1)$} & & $-0.237 * * *$ & & & \\
\hline & & $(0.015)$ & & & \\
\hline \multirow[t]{2}{*}{ Ln(spouse's income) } & & $-0.0249 * * *$ & & & \\
\hline & & $(0.002)$ & & & \\
\hline \multirow[t]{2}{*}{ Ln(capital income) } & & -0.0023 & & & \\
\hline & & $(0.002)$ & & & \\
\hline
\end{tabular}


Table 7. Linear Probability Model Estimates for Pension Participation Components (cont'd)

\begin{tabular}{lccccc}
\hline Dependent Variable & Participate & Working & Offer & Eligible & Participate \\
\hline Sample & All & All & Working & Offer & Eligible \\
\hline Pink collar & -0.0193 & & 0.0389 & 0.0281 & $-0.0534^{*}$ \\
& $(0.031)$ & & $(0.029)$ & $(0.029)$ & $(0.030)$ \\
Blue collar & $-0.11^{* * *}$ & & $-0.0652^{* *}$ & 0.0271 & $-0.0466^{*}$ \\
& $(0.028)$ & & $(0.029)$ & $(0.029)$ & $(0.026)$ \\
Job tenure & $0.014^{* * *}$ & & $0.007 * * *$ & $0.007^{* * *}$ & $0.007^{* * *}$ \\
& $(0.001)$ & & $(0.001)$ & $(0.001)$ & $(0.001)$ \\
Small firm & $-0.259^{* * *}$ & & $-0.39^{* * *}$ & 0.0010 & 0.0298 \\
& $(0.023)$ & & $(0.024)$ & $(0.027)$ & $(0.028)$ \\
Medium firm & $-0.0844^{* * *}$ & & $-0.152^{* * *}$ & 0.023 & -0.0072 \\
& $(0.030)$ & & $(0.031)$ & $(0.022)$ & $(0.032)$ \\
Union member & $0.192^{* * *}$ & & $0.15^{* * *}$ & $0.0587 * * *$ & $0.0526^{* *}$ \\
& $(0.025)$ & & $(0.021)$ & $(0.018)$ & $(0.023)$ \\
Ln(personal income) & $0.0297^{* * *}$ & & $0.0153^{* *}$ & $0.0183^{* *}$ & $0.0205^{* *}$ \\
& $(0.006)$ & & $(0.007)$ & $(0.008)$ & $(0.008)$ \\
Working & 0.101 & & & & \\
& $(0.064)$ & & & & \\
$\mathrm{N}$ & 7,891 & 7,930 & 3,741 & 2,181 & 1,951 \\
$\mathrm{R}^{2}$ & 0.523 & 0.616 & 0.304 & 0.129 & 0.138 \\
\hline
\end{tabular}

Note: All regressions include wave and region dummies. ${ }^{* * *} \mathrm{p}<0.01,{ }^{* *} \mathrm{p}<0.05,{ }^{*} \mathrm{p}<0.1$.

Source: Authors' calculations from the Health and Retirement Study (1992-2010). 
Table 8. Fixed Effects Estimates for Pension Participation Components

\begin{tabular}{|c|c|c|c|c|c|}
\hline Dependent variable & Participate & Working & Offer & Eligible & Participate \\
\hline Sample & All & All & Working & Offer & Eligible \\
\hline \multirow[t]{2}{*}{ Age } & -0.0056 & -0.0097 & -0.0049 & -0.0029 & -0.0409 \\
\hline & $(0.014)$ & $(0.014)$ & $(0.036)$ & $(0.031)$ & $(0.030)$ \\
\hline \multirow{2}{*}{ Married } & 0.0225 & -0.0278 & -0.0655 & 0.166 & $0.226 *$ \\
\hline & $(0.027)$ & $(0.027)$ & $(0.069)$ & $(0.141)$ & $(0.124)$ \\
\hline \multirow[t]{2}{*}{ Household size } & -0.0030 & -0.0054 & $-9 \mathrm{E}-05$ & 0.0084 & -0.0005 \\
\hline & $(0.005)$ & $(0.007)$ & $(0.018)$ & $(0.018)$ & $(0.012)$ \\
\hline \multirow[t]{2}{*}{ Homeowner } & $0.067 *$ & $0.67 * * *$ & -0.0926 & 0.0158 & -0.0715 \\
\hline & $(0.035)$ & $(0.035)$ & $(0.065)$ & $(0.075)$ & $(0.047)$ \\
\hline \multirow{2}{*}{ Least risk averse } & 0.0204 & 0.0183 & -0.0228 & 0.00434 & 0.116 \\
\hline & $(0.025)$ & $(0.033)$ & $(0.075)$ & $(0.065)$ & $(0.081)$ \\
\hline \multirow[t]{2}{*}{ 2nd least risk averse } & -0.007 & -0.0274 & 0.0268 & 0.0382 & -0.0231 \\
\hline & $(0.027)$ & $(0.032)$ & $(0.081)$ & $(0.044)$ & $(0.038)$ \\
\hline \multirow[t]{2}{*}{ Medium risk aversion } & 0.0069 & 0.0281 & -0.0607 & 0.0441 & -0.0316 \\
\hline & $(0.022)$ & $(0.024)$ & $(0.048)$ & $(0.046)$ & $(0.039)$ \\
\hline \multirow[t]{2}{*}{ Fair or poor health } & & -0.0162 & & & \\
\hline & & $(0.015)$ & & & \\
\hline \multirow[t]{2}{*}{ Disability benefits (0/1) } & & $-0.13 * * *$ & & & \\
\hline & & $(0.038)$ & & & \\
\hline \multirow[t]{2}{*}{ Health limitation (0/1) } & & $-0.11 * * *$ & & & \\
\hline & & $(0.023)$ & & & \\
\hline \multirow[t]{2}{*}{ Ln(spouse's income) } & & $-0.0106^{* * *}$ & & & \\
\hline & & $(0.002)$ & & & \\
\hline \multirow[t]{2}{*}{ Ln(capital income) } & & 0.00254 & & & \\
\hline & & $(0.003)$ & & & \\
\hline \multirow[t]{2}{*}{ Pink collar } & -0.0667 & & -0.147 & 0.229 & $0.384 *$ \\
\hline & $(0.064)$ & & $(0.120)$ & $(0.196)$ & $(0.233)$ \\
\hline \multirow[t]{2}{*}{ Blue collar } & $-0.187 * * *$ & & $-0.216^{*}$ & $0.296 *$ & 0.307 \\
\hline & $(0.065)$ & & $(0.131)$ & $(0.179)$ & $(0.216)$ \\
\hline \multirow[t]{2}{*}{ Job tenure } & $0.016 * * *$ & & $0.009 * *$ & $0.015^{* *}$ & 0.007 \\
\hline & $(0.003)$ & & $(0.004)$ & $(0.006)$ & $(0.004)$ \\
\hline \multirow[t]{2}{*}{ Small firm } & $-0.13 * * *$ & & $-0.178 * * *$ & 0.0495 & -0.0984 \\
\hline & $(0.043)$ & & $(0.063)$ & $(0.074)$ & $(0.104)$ \\
\hline \multirow[t]{2}{*}{ Medium firm } & -0.0153 & & -0.0681 & $0.239 *$ & $-0.288 * *$ \\
\hline & $(0.053)$ & & $(0.086)$ & $(0.139)$ & $(0.136)$ \\
\hline \multirow[t]{2}{*}{ Union member } & $0.242 * * *$ & & 0.129 & $0.225 *$ & 0.0166 \\
\hline & $(0.064)$ & & $(0.080)$ & $(0.126)$ & $(0.069)$ \\
\hline \multirow[t]{2}{*}{ Ln(personal income) } & $0.0195 * *$ & & -0.0175 & $0.0554 * * *$ & $0.0264 *$ \\
\hline & $(0.010)$ & & $(0.013)$ & $(0.018)$ & $(0.016)$ \\
\hline
\end{tabular}


Table 8. Fixed Effects Estimates for Pension Participation Components (cont'd)

\begin{tabular}{lccccc}
\hline Dependent variable & Participate & Working & Offer & Eligible & Participate \\
\hline Sample & All & All & Working & Offer & Eligible \\
\hline Working & 0.0838 & & & & \\
& $(0.113)$ & & & & \\
\hline N (person-waves) & 7,895 & 7,934 & 3,742 & 2,181 & 1,951 \\
N (unique persons) & 4,699 & 4,708 & 2,480 & 1,538 & 1,375 \\
$\mathrm{R}^{2}$ & 0.199 & 0.411 & 0.0614 & 0.171 & 0.18 \\
\hline
\end{tabular}

Note: All regressions include wave and region dummies. ${ }^{* * *} \mathrm{p}<0.01,{ }^{* *} \mathrm{p}<0.05, * \mathrm{p}<0.1$.

Source: Authors' calculations from the Health and Retirement Study (1992-2010). 
Table 9. Regression Estimates for DB and DC Pension Offers

\begin{tabular}{|c|c|c|c|c|}
\hline \multirow{2}{*}{$\begin{array}{l}\text { Specification } \\
\text { Dependent variable }\end{array}$} & \multicolumn{2}{|c|}{ Linear probability model } & \multicolumn{2}{|c|}{ Fixed effects LPM } \\
\hline & Offer DB & Offer DC & Offer DB & Offer DC \\
\hline Sample & Working & Working & Working & Working \\
\hline Age & $\begin{array}{r}-0.003 \\
(0.003)\end{array}$ & $\begin{array}{r}-0.00195 \\
(0.004)\end{array}$ & $\begin{array}{r}-0.0026 \\
(0.019)\end{array}$ & $\begin{array}{r}-0.0106 \\
(0.030)\end{array}$ \\
\hline Married & $\begin{array}{l}0.0213 \\
(0.013)\end{array}$ & $\begin{array}{r}-0.0172 \\
(0.017)\end{array}$ & $\begin{array}{r}0.028 \\
(0.052)\end{array}$ & $\begin{array}{r}0.0143 \\
(0.096)\end{array}$ \\
\hline Household size & $\begin{array}{r}-0.00096 \\
(0.004)\end{array}$ & $\begin{array}{r}-0.00363 \\
(0.004)\end{array}$ & $\begin{array}{r}-0.00182 \\
(0.010)\end{array}$ & $\begin{array}{r}-0.0132 \\
(0.011)\end{array}$ \\
\hline Homeowner & $\begin{array}{r}0.000442 \\
(0.012)\end{array}$ & $\begin{array}{l}0.0231 \\
(0.015)\end{array}$ & $\begin{array}{r}-0.0391 \\
(0.053)\end{array}$ & $\begin{array}{r}-0.00363 \\
(0.062)\end{array}$ \\
\hline Pink collar & $\begin{array}{r}-0.00596 \\
(0.019)\end{array}$ & $\begin{array}{l}0.0544 * * \\
(0.024)\end{array}$ & $\begin{array}{l}0.0121 \\
(0.049)\end{array}$ & $\begin{array}{r}-0.0256 \\
(0.083)\end{array}$ \\
\hline Blue collar & $\begin{array}{l}-0.0478 * * \\
(0.019)\end{array}$ & $\begin{array}{r}0.00893 \\
(0.022)\end{array}$ & $\begin{array}{r}0.042 \\
(0.045)\end{array}$ & $\begin{array}{r}-0.1 \\
(0.096)\end{array}$ \\
\hline Job tenure & $\begin{array}{l}0.00407^{* * *} \\
(0.001)\end{array}$ & $\begin{array}{r}0.000222 \\
(0.001)\end{array}$ & $\begin{array}{r}0.00533 \\
(0.004)\end{array}$ & $\begin{array}{r}0.00642 \\
(0.005)\end{array}$ \\
\hline Small firm & $\begin{array}{l}-0.117 * * * \\
(0.014)\end{array}$ & $\begin{array}{l}-0.13^{* * *} \\
(0.018)\end{array}$ & $\begin{array}{l}-0.084 * * \\
(0.038)\end{array}$ & $\begin{array}{r}-0.0349 \\
(0.045)\end{array}$ \\
\hline Medium firm & $\begin{array}{l}-0.0473 * * * \\
(0.018)\end{array}$ & $\begin{array}{l}-0.0441^{*} \\
(0.023)\end{array}$ & $\begin{array}{r}-0.0379 \\
(0.036)\end{array}$ & $\begin{array}{r}-0.0532 \\
(0.071)\end{array}$ \\
\hline Least risk Aa & $\begin{array}{l}-0.0707 * * * \\
(0.016)\end{array}$ & $\begin{array}{l}-0.0379 * \\
(0.020)\end{array}$ & $\begin{array}{r}-0.039 \\
(0.062)\end{array}$ & $\begin{array}{r}-0.127 \\
(0.081)\end{array}$ \\
\hline 2nd least risk averse & $\begin{array}{r}-0.018 \\
(0.019)\end{array}$ & $\begin{array}{r}-0.0123 \\
(0.025)\end{array}$ & $\begin{array}{r}-0.0658 \\
(0.046)\end{array}$ & $\begin{array}{r}0.0236 \\
(0.044)\end{array}$ \\
\hline Medium risk aversion & $\begin{array}{r}-0.026 \\
(0.016)\end{array}$ & $\begin{array}{l}0.0221 \\
(0.022)\end{array}$ & $\begin{array}{l}-0.0795 * \\
(0.042)\end{array}$ & $\begin{array}{r}-0.0275 \\
(0.057)\end{array}$ \\
\hline Previous pension & $\begin{array}{l}0.0196 \\
(0.014)\end{array}$ & $\begin{array}{r}-0.0264 \\
(0.016)\end{array}$ & & \\
\hline Union member & $\begin{array}{l}0.142 * * * \\
(0.019)\end{array}$ & $\begin{array}{l}0.0261 \\
(0.021)\end{array}$ & $\begin{array}{r}-0.0456 \\
(0.059)\end{array}$ & $\begin{array}{r}-0.129 \\
(0.081)\end{array}$ \\
\hline Ln(personal income) & $\begin{array}{r}-0.00415 \\
(0.006)\end{array}$ & $\begin{array}{r}0.00192 \\
(0.006)\end{array}$ & $\begin{array}{r}-0.0111 \\
(0.011)\end{array}$ & $\begin{array}{r}-0.00021 \\
(0.011)\end{array}$ \\
\hline N (person-waves) & 3,741 & 3,741 & 3,742 & 3,742 \\
\hline $\begin{array}{l}\mathrm{N} \text { (unique persons) } \\
\mathrm{R}^{2}\end{array}$ & 0.263 & 0.113 & $\begin{array}{l}2,480 \\
0.104\end{array}$ & $\begin{array}{r}2,480 \\
0.0798 \\
\end{array}$ \\
\hline
\end{tabular}

Note: All regressions include wave and region dummies. Cross-sectional model (first two columns) also includes female, race categories, and educational attainment categories. ${ }^{* * *} \mathrm{p}<0.01,{ }^{* *} \mathrm{p}<0.05,{ }^{*} \mathrm{p}<0.1$.

Source: Authors' calculations from the Health and Retirement Study (1992-2010). 
Appendix Table 1. Sample Selection Criteria

\begin{tabular}{lrr}
\hline Criterion & Person Waves & Unique Person \\
\hline HRS 1992-2010 with non-zero weights & 160,742 & 27,813 \\
Age 50-58 & 38,185 & 7538 \\
Under 300\% PL & 14,200 & 3069 \\
Not Self Employed & 12,949 & 2771 \\
Subsamples & & \\
$\quad$ Working & 6,369 & 1448 \\
$\quad$ Offered Pension & 3,595 & 776 \\
$\quad$ Eligible Pension & 3,243 & 702 \\
$\quad$ Take Up Pension & 2,823 & 635 \\
\hline
\end{tabular}

Source: Authors' calculations from the Health and Retirement Study (1992-2010). 


\section{RECENT WORKING PAPERS FROM THE CENTER FOR RETIREMENT RESEARCH AT BOSTON COLLEGE}

How Do Subjective Longevity Expectations Influence Retirement Plans?

Mashfiqur R. Khan, Matthew S. Rutledge, and April Yanyuan Wu, January 2014

Impact of the Great Recession on Retirement Trends in Industrialized Countries Gary Burtless and Barry P. Bosworth, December 2013

Does Household Debt Influence the Labor Supply and Benefit Claiming Decisions of Older Americans?

Barbara A. Butrica and Nadia S. Karamcheva, December 2013

Point of No Return: How Do Financial Resources Affect the Timing of Retirement After a Job Separation?

Matthew S. Rutledge, December 2013

The Medicaid Buy-In and Social Security Disability Insurance (DI) Beneficiaries: Lessons for the 2014 Medicaid Expansion and Proposals to Reform DI

Melissa McInerney, December 2013

Validating Longitudinal Earnings in Dynamic Microsimulation Models: The Role of Outliers

Melissa M. Favreault and Owen Haaga, September 2013

Housing in Retirement Across Countries

Makoto Nakajima and Irina A. Telyukova, August 2013

Can Benefits and Work Incentives Counseling Be a Path to Future Economic SelfSufficiency for SSI/SSDI Beneficiaries?

Zafar E. Nazarov, August 2013

How Do the Changing Labor Supply Behavior and Marriage Patterns of Women Affect Social Security Replacement Rates?

April Yanyuan Wu, Nadia S. Karamcheva, Alicia H. Munnell, Patrick Purcell, July 2013

Social Security and the 2001 Reform of the Railroad Retirement Program

Steven A. Sass, June 2013

An Assessment of the 2001 Reform of the Railroad Retirement Program

Steven A. Sass, June 2013

All working papers are available on the Center for Retirement Research website (http://crr.bc.edu) and can be requested by e-mail (crr@bc.edu) or phone (617-552-1762). 